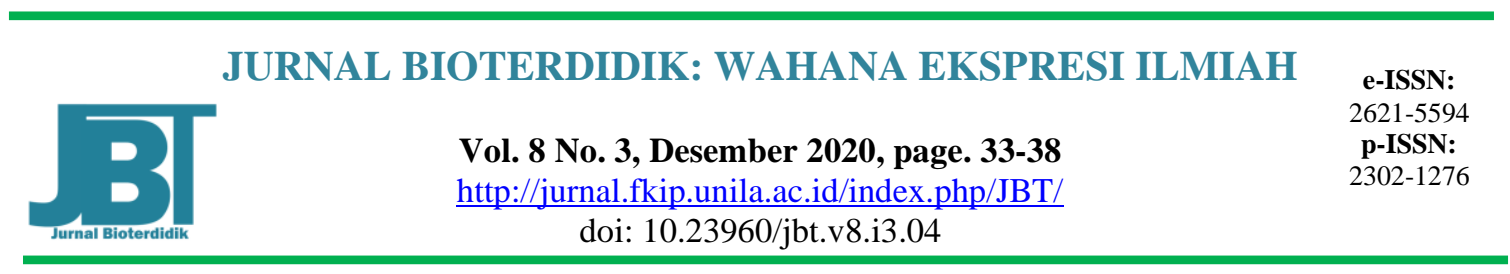

\title{
Pengaruh Pembelajaran IPA Menggunakan Media Puzzle Terhadap Berpikir Kritis Peserta Didik
}

\author{
Tika Wulandari, Rini Rita T Marpaung, Darlen Sikumbang \\ Pendidikan Biologi, Fakultas Keguruan dan Ilmu Pendidikan, Universitas Lampung, Jl. Prof. Dr. \\ Soemantri Brojonegoro No. 1 Bandar Lampung, Indonesia \\ email: ritamarpaung15@gmail.com
}

\begin{abstract}
The Effect of Science Learning Using Puzzle Media on Student's Critical Thinking. This research aims to determine the effect of puzzle media on students critical thinking. The study population was all grade VII students at SMP Muhammadiyah 3 Bandar Lampung totaling 192 people. The research sample was students from 2 classes, namely class VII A and VII B who were selected from the population by using purposive sampling technique. The research instrument used a pretest-posttest sheet. The design used is the nonequivalent control group design. The data analysis used t-test at a significance level of 5\% which shows the results of the sig value. (2-tailed) $0.00<0.05$, which means that the average $n$-Gain learning outcomes of students' critical thinking skills between the experimental class and the control class differed significantly. This is due to the using puzzle media, because students are trained to think critically through using puzzle media during the learning process. Thus, it is known that using puzzle media can affect the critical thinking skills of students.
\end{abstract}

Keywords: critical thinking, puzzle media, science

Abstrak: Pengaruh Pembelajaran IPA Menggunakan Media Puzzle Terhadap Berpikir Kritis Peserta Didik. Penelitian ini bertujuan untuk menentukan pengaruh media puzzle terhadap berpikir kritis peserta didik. Populasi penelitian adalah seluruh peserta didik kelas VII di SMP Muhammadiyah 3 Bandar Lampung berjumlah 192 orang. Sampel penelitian adalah peserta didik dari 2 kelas yaitu kelas VII A dan VII B yang dipilih dari populasi dengan teknik purposive sampling. Instrumen penelitian menggunakan lembar pretes-postes. Desain yang digunakan yaitu nonequivalent control group design. Analisis data yang digunakan Uji t- test pada taraf signifikansi 5\% yang menunjukkan hasil nilai sig. (2-tailed) $0,00<0,05$ yang berarti n-Gain rata-rata hasil belajar kemampuan berpikir kritis peserta didik antara kelas eksperimen dan kelas kontrol berbeda signifikan. Hal tersebut disebabkan oleh penggunaan media puzzle, karena peserta didik dilatih untuk berpikir kritis melalui media puzzle saat proses pembelajaran berlangsung. Dengan demikian, diketahui bahwa menggunakan media puzzle dapat berpengaruh terhadap kemampuan berpikir kritis peserta didik.

Kata kunci: berpikir kritis, media puzzle, sains 


\section{PENDAHULUAN}

Kerangka kompetensi abad ke-21 menjadi pijakan dalam perkembangan Kurikulum 2013. Salah satu kompetensi yang harus dimiliki oleh anak-anak di abad ke-21 yaitu kemampuan berpikir kritis. Salah satu isi yang terkandung dalam kurikulum tersebut adalah pendidik dituntut untuk merubah mindset karena dalam point proses menurut Kemendikbud (2013:16) bahwa untuk merubah mindset haruslah berorientasi pada karakteristik kompetensi (sikap, keterampilan, pengetahuan), menggunakan pendekatan ilmiah (scientific), karakteristik kompetensi setiap jenjang dan mengutamakan strategi pembelajaran Discovery learning, strategi pembelajaran Project based learning dan strategi pembelajaran Problem based learning. Strategi pembelajaran Discovery learning tersebut dapat membuat peserta didik mengkonstruksi pengetahuannya sendiri menemukan pengetahuannya sendiri sehingga pembelajarannya akan lebih bermakna dan pada akhirnya peserta didik akan mendapat sesuatu yang bermanfaat bagi dirinya setelah selesai pembelajaran.

Pembelajaran menarik yang dapat mendorong peserta didik untuk terlibat aktif dalam belajar salah satunya dengan menggunakan media permainan. Salah satu media yang dapat digunakan untuk meningkatkan motivasi dan aktivitas belajar peserta didik adalah media puzzle. Media puzzle juga dapat disebut permainan edukasi karena tidak hanya untuk bermain tetapi juga mengasah otak dan melatih antara kecepatan pikiran dan tantangan (Yudha dalam Rosiana Khomsoh, 2007:33). Dengan media puzzle siswa dapat belajar secara nyaman melalui permainan untuk menyelesaikan masalah yang berhubungan dengan materi pelajaran. Dalam kegiatan belajar mengajar dengan media puzzle siswa mencoba memecahkan masalah dengan kreatifitas siswa.

Berdasarkan wawancara kepada pendidik mata pelajaran IPA yang dilakukan di SMP 3 Muhammadiyah Bandar Lampung, nilai peserta didik pada mata pelajaran IPA masih rendah dibawah Kriteria Ketuntasan Minimal (KKM) yang telah ditetapkan yaitu 65. Hal ini disebabkan karena pembelajaran bersifat konvensional dan lebih berpusat kepada pendidik atau teacher centered. Saat proses pembelajaran, peserta didik kurang aktif dalam mengikuti proses belajar mengajar karena kurangnya motivasi dan rasa percaya diri peserta didik. Selain itu, proses pembelajaran yang masih menggunakan metode ceramah, belum menggunakan media belajar, dan penugasan mengakibatkan peserta didik menjadi tidak aktif, kegiatan belajar mengajar yang monoton sehingga menjadi tidak menyenangkan dan kurang bermakna bagi peserta didik, serta kurang optimalnya tingkat berpikir peserta didik dalam mengikuti pembelajaran.

Salah satu model yang dapat digunakan dalam meningkatkan kemampuan berpikir kritis dan hasil belajar peserta didik yaitu model pembelajaran Discovery learning. Ketertarikan tersebut bukan tanpa alasan, karena pembelajaran tersebut dapat membuat peserta didik mengkonstruksi pengetahuannya sendiri, menemukan pengetahuannya sendiri sehingga pembelajarannya akan lebih bermakna kepada peserta didik dan pada akhirnya peserta didik akan mendapat sesuatu yang bermanfaat bagi dirinya setelah selesai pembelajaran. Keuntungan menggunakan metode Discovery learning ini adalah akan menjadikan peserta didik aktif dalam mengeluarkan gagasan dan bisa membantu peserta didik untuk memperkuat konsep belajarnya sehingga secara tidak langsung dapat meningkatkan kepercayaan diri dari peserta didik. Untuk menjadikan kegiatan belajar menjadi tidak monoton, media puzzle menjadi salah satu media pembelajaran yang dapat digunakan di dalam kelas. Penggunaan media puzzle dalam pembelajaran dapat membantu peserta didik dalam memahami dan meningkatkan perhatian peserta didik terhadap isi materi yang diajarkan. 
Berdasarkan uraian di atas maka dilakukan penelitian yang bertujuan untuk mengetahui pengaruh penggunaan media puzzle terhadap berpikir kritis peserta didik.

\section{METODE}

Penelitian ini dilaksanakan pada semester genap bulan Febuari 2020 di SMP Muhammadiyah 3 Bandar Lampung. Populasi dalam penelitian ini adalah seluruh peserta didik kelas VII semester genap SMP Muhammadiyah 3 Bandar Lampung dengan sampel penelitian kelas VII A sebagai kelas kontrol dan VII B sebagai kelas eksperimen yang dipilih dengan teknik purposive sampling. Penelitian ini merupakan eksperimental semu (quasi eksperimental design) dengan desain pretes-postes (Tabel 1).

Tabel 1. Desain penelitian

\begin{tabular}{lccc}
\hline \multicolumn{1}{c}{ Kelas } & Pretes & Perlakuan & Posttest \\
\hline Eksperimen & $\mathrm{O}_{1}$ & $\mathrm{X}$ & $\mathrm{O}_{2}$ \\
\hline Kontrol & $\mathrm{O}_{3}$ & - & $\mathrm{O}_{4}$ \\
\hline
\end{tabular}

Kedua kelompok diberi tes berupa soal essai sebanyak 10 soal di awal dan diakhir kegiatan pembelajaran (pretes-postes). Data dalam penelitian ini berupa data kuantitatif yang diperoleh dari nilai pretes-postes, dan $\mathrm{N}$-gain yang dianalisis secara statistik menggunakan uji $\mathrm{t}$ dengan taraf kepercayaan 5\% namun sebelumnya dilakukan uji prasyarat berupa uji normalitas dan uji homogenitas.

\section{HASIL DAN PEMBAHASAN}

Data hasil belajar kognitif peserta didik diperoleh dari nilai pretes, postes dan $\mathrm{N}$ gain yang dapat dilihat pada Tabel 2 .

Tabel 2. Hasil tabulasi uji statistik pretes, postes, dan N-gain

\begin{tabular}{|c|c|c|c|c|c|}
\hline Nilai & Kelas & Rerata & Uji Normalitas & $\begin{array}{c}\text { Uji } \\
\text { Homogenitas }\end{array}$ & $\begin{array}{c}\mathrm{Uji} \\
\text { Independent } \\
\text { Sample t-test. }\end{array}$ \\
\hline \multirow[t]{2}{*}{ Pretes } & $\mathrm{E}$ & 58,34 & Sig $0,52>0,05$ & \multirow[t]{2}{*}{ Sig $0,72>0,05$} & \multirow{4}{*}{$\begin{array}{l}\text { Sig (2-tailed }) \\
0,00<0,05\end{array}$} \\
\hline & $\mathrm{K}$ & 57,50 & Sig $0,11>0,05$ & & \\
\hline \multirow[t]{2}{*}{ Postes } & $E$ & 69,21 & Sig $0,35>0,05$ & \multirow[b]{2}{*}{$\begin{array}{l}\text { Sig } 0,006> \\
0,05\end{array}$} & \\
\hline & $\mathrm{K}$ & 67,23 & Sig $0,28>0,05$ & & \\
\hline \multirow[t]{2}{*}{$\mathrm{N}$-gain } & $\mathrm{E}$ & 24,81 & Sig $0,742>0,05$ & \multirow{2}{*}{$\begin{array}{l}\text { Sig } 0,776> \\
0,05\end{array}$} & \multirow{2}{*}{$\begin{array}{l}\text { Sig (2-tailed) } \\
0,00<0,05\end{array}$} \\
\hline & $\mathrm{K}$ & 22,63 & Sig $0,633>0,05$ & & \\
\hline
\end{tabular}

Keterangan : $\mathrm{E}=$ Eksperimen, $\mathrm{K}=$ Kontrol

Tabel 2 menunjukkan bahwa nilai pretes, postes, dan $\mathrm{N}$-gain pada kelas eksperimen lebih tinggi daripada kelas kontrol. Hasil uji normalitas menunjukkan keputusan uji terima $\mathrm{H}_{0}$ dan tolak $\mathrm{H}_{1}$ yang berarti bahwa data diperoleh dari sampel yang berdistribusi normal. Selanjutnya pada uji homogenitas diperoleh keputusan uji terima $\mathrm{H}_{0}$ dan tolak $\mathrm{H}_{1}$ yang berarti bahwa data penelitian adalah homogen. Pada uji Independent Sample t-test menunjukkan nilai sig. (2-tailed) $0,00<0,05$ yang berarti kemampuan berpikir kritis antara kelas kontrol dengan kelas eksperimen berbeda signifikan. 
Tabel 3 menunjukkan Pada kelas eksperimen rata-rata pretes yang diperoleh yaitu $57 \pm 8$ dengan kriteria rendah, dan rata-rata postes yang diperoleh yaitu $68 \pm 9$ dengan kriteria sedang. Sedangkan pada kelas kontrol rata-rata pretes yang diperoleh yaitu $57 \pm$ 4,6 dengan kriteria rendah, dan rata-rata postes yang diperoleh yaitu $67 \pm 3$,8dengan kriteria sedang. Untuk dapat mengetahui perbedaan ketercapaian peserta didik dari masing-masing aspek berpikir kritis, maka dilakukan analisis rata-rata pada setiap indikator berpikir kritis (Tabel 3).

Tabel 3. Hasil Analisis Rata-Rata Setiap Indikator Berpikir Kritis pada Kelas Eksperimen dan Kontrol

\begin{tabular}{|c|c|c|c|c|c|c|}
\hline Kelas & Indikator & $\begin{array}{c}\text { Rata- } \\
\text { Rata } \\
\text { Pretes } \pm \\
\text { StDev }\end{array}$ & $\begin{array}{c}\text { Rata- } \\
\text { Rata } \\
\text { Postes } \pm \\
\text { StDev }\end{array}$ & Kelas & $\begin{array}{c}\text { Rata- } \\
\text { Rata } \\
\text { Pretes } \pm \\
\text { StDev }\end{array}$ & $\begin{array}{c}\text { Rata- } \\
\text { Rata } \\
\text { Postes } \pm \\
\text { StDev }\end{array}$ \\
\hline \multirow[t]{2}{*}{$\mathbf{E}$} & Elementary clarification & 68 & 80 & \multirow[t]{2}{*}{$\mathrm{K}$} & 63 & 72 \\
\hline & Kriteria & Sedang & Tinggi & & Sedang & Sedang \\
\hline \multirow[t]{2}{*}{$\mathbf{E}$} & Inference & 54 & 63 & \multirow[t]{2}{*}{$\mathrm{K}$} & 58 & 66 \\
\hline & Kriteria & Rendah & Sedang & & Rendah & Sedang \\
\hline \multirow[t]{2}{*}{$\mathbf{E}$} & Advanced clarification & 49 & 59 & \multirow[t]{2}{*}{$\mathrm{K}$} & 52 & 63 \\
\hline & Kriteria & Rendah & Sedang & & Rendah & Sedang \\
\hline \multirow[t]{4}{*}{$\mathbf{E}$} & Strategies and tactics & 56 & 70 & \multirow[t]{4}{*}{$\mathrm{K}$} & 56 & 67 \\
\hline & Kriteria & Rendah & Sedang & & Rendah & Sedang \\
\hline & Rata-rata \pm StDev & $57 \pm 8$ & $68 \pm 9$ & & $57 \pm 4,6$ & $67 \pm 3,8$ \\
\hline & Kriteria & Rendah & Sedang & & Rendah & Sedang \\
\hline
\end{tabular}

Keterangan : $\mathrm{E}=$ Eksperimen, $\mathrm{K}=$ Kontrol

Hasil penelitian yang telah dilakukan pada peserta didik kelas VII di SMP Muhammadiyah 3 Bandar Lampung menunjukkan bahwa penerapan model pembelajaran Discovery learning menggunakan media puzzle berpengaruh terhadap kemampuan berpikir kritis peserta didik. Hal ini dapat dilihat dari hasil analisis pada Tabel 2 yang menunjukan bahwa kemampuan berpikir kritis peserta didik pada kelas eksperimen lebih baik daripada kelas kontrol. Pada kelas eksperimen rata-rata nilai pretes sebesar 58,3; rata-rata nilai postes sebesar 69,2; dan $\mathrm{N}$-gain sebesar 24,8. Sedangkan pada kelas kontrol rata-rata nilai pretes sebesar 57,5; rata-rata nilai postes sebesar 67,2; dan N-gain sebesar 22,6 . Hal ini disebabkan, saat proses pembelajaran menggunakan media puzzle peserta didik kelas eksperimen melakukan tahapan-tahapan yang sistematis seperti orientasi oleh pendidik untuk menumbuhkan rasa keingintahuan peserta didik terhadap materi yang akan dipelajari, kemudian peserta didik diberikan kesempatan untuk melakukan identifikasi dan eksplorasi untuk mengumpulkan data guna menjawab rumusan masalah dan hipotesis pembelajaran. Menurut Rusyan (1992 : 177), dalam belajar penemuan (Discovery learning) pendidik menyajikan bahan pelajaran tidak dalam bentuknya yang final, tetapi peserta didik yang diberi peluang untuk mencari dan menemukannya sendiri. Dengan demikian, kemampuan berpikir kritis peserta didik dapat dikembangkan.

Keberhasilan pencapaian kemampuan berpikir kritis peserta didik pada penelitian ini disebabkan karena saat proses pembelajaran, peserta didik dihadapkan dengan suatu masalah atau situasi yang tampaknya ganjil, sehingga peserta didik dapat mencari solusi atau jalan keluar untuk masalah tersebut dengan diberikan kesempatan kepada peserta didik untuk ikut serta secara aktif dalam melakukan observasi atau suatu tindakan ilmiah agar sampai pada suatu penemuan atau kesimpulan dan diharapkan hasil pembelajaran akan tahan lama dalam ingatan peserta didik, karena peserta didik membangun sendiri pengetahuan yang didapat selama proses pembelajaran dan tidak berpusat pada pendidik. 
Media puzzle juga berperan dalam peningkatan kemampuan berpikir kritis peserta didik, dikarenakan dapat mengasah otak untuk kecerdasan dan melatih peserta didik bekerjasama dalam sebuah tim untuk memecahkan masalah.

Model pembelajaran Discovery Learning dapat meningkatkan kemampuan berpikir kritis peserta didik jika setiap sintaks dilaksanakan dengan baik. Hal ini didukung oleh pernyataan (Nursyamsudin, 2013: 5) menyatakan bahwa pembelajaran yang menggunakan Discovery learning dapat meningkatkan kemampuan berpikir kritis peserta didik karena peserta didik dilatih untuk mengamati, menanya, mencoba, menalar dan mengkomunikasikan melalui sintaksnya seperti pada tahap stimulation peserta didik diajak untuk mengamati dan menanya, tahap problem statement siswa diajak untuk mencoba dan mengamati, tahap data processing siswa diajak untuk menalar dan menanya dan tahap terakhir verification siswa diajak untuk menalar, dan mengkomunikasikan. Pada saat proses penelitian, keterlaksanaan masing-masing sintaks dari model pembelajaran Discovery Learning menunjukkan bahwa hampir seluruh kegiatan terlaksana pada tiap sintaks.

\section{SIMPULAN}

Berdasarkan hasil penelitian dan pembahasan, maka dapat disimpulkan bahwa terdapat pengaruh penggunaan media puzzle terhadap tingkat berpikir kritis peserta didik.

\section{DAFTAR RUJUKAN}

Kemendikbud. 2013. Materi Pelatihan Guru Implementasi Kurikulum 2013 SMP/MTs matematika. Kementrian Pendidikan Dan Kebudayaan. Jakarta.

Nursyamsuddin, dkk. 2013. Pembelajaran Berbasis Kompetensi dengan Pendekatan Saintifik. Kemendikbud RI. Jakarta.

Rosiana, K. 2013. Penggunaan Media Puzzle untuk Meningkatkan Hasil Belajar Siswa dalam Pembelajaran Ilmu Pengetahuan Sosial di Sekolah Dasar. Vol.1(2) : 33.

Rusyan, A. T., Kusdaniae, A., \&Arifin, Z. 1992. Pendekatan Dalam proses Belajar mengajar. Remaja Rosdakarya. Bandung. 
Jurnal Bioterdidik, Vol. 8 No. 3, Desember 2020 